\title{
Characterization of Four Specimens of Allium sativum L. by Differential Karyotype and RAPD Analysis
}

\author{
Amika Ahmed Manzum, Syeda Sharmeen Sultana, Ashma Ahmed Warasy, \\ Rokeya Begum and Sheikh Shamimul Alam*
}

Department of Botany, University of Dhaka, Dhaka-1000, Bangladesh

Received April 11, 2014; accepted July 20, 2014

\begin{abstract}
Summary Four specimens of Garlic (Allium sativum L.), viz., Local monocloved, Local multicloved, Indian multicloved and a wild specimen (a tribal specimen locally called Joldong), were compared karyotypically by differential staining with orcein, CMA and DAPI. In addition, DNA fingerprinting was carried out by using RAPD. The wild specimen was found to possess $2 n=32$ chromosomes while the other three specimens had $2 n=16$ chromosomes with more or less similar total length of $2 n$ chromosome complement. The four specimens showed distinct centromeric formulae, i.e. $12 \mathrm{~m}+4 \mathrm{sm}$ in Local monocloved, $8 \mathrm{~m}+8 \mathrm{sm}$ in Local multicloved, $10 \mathrm{~m}+6 \mathrm{sm}$ in Indian multicloved and $26 \mathrm{~m}+6 \mathrm{sm}$ in the wild specimen. In Local monocloved, a unique structure in a pair of sub-metacentric chromosomes revealed the occurrence of homozygous paracentric inversion. The four specimens of Allium sativum L. have distinct CMA- and DAPI-banding patterns. Asymmetric banding patterns in homologue members indicated minute chromosomal alterations. The two entirely DAPI fluoresced chromosomes were found in only the Local monocloved specimen. These chromosomes were unique and thus could be used as marker chromosomes for this specimen. Each specimen showed characteristic RAPD fingerprinting. The unique RAPD fragments could be used as markers for the respective specimens. Differential karyotype analysis did not support to consider the multicloved specimens as autotetraploid of the monocloved, inspite of having gigas features. The wild specimen showed a completely different karyotype than the other three specimens. It was placed alone in a separate cluster on the basis of RAPD analysis with highest genetic distance. Therefore, a thorough investigation is necessary to elucidate the taxonomic status of this wild specimen.
\end{abstract}

Key words Fluorescent karyotype, Allium sativum L., RAPD, Differential staining.

Allium sativum L. is a member of the family Liliaceae. It is commonly known as garlic. Allium longicuspis Regd. is considered as an endemic wild ancestor of Allium sativum L. (Siddiqui et al. 2007). There are few different germplasms of Allium sativum L. available in Bangladesh. These are classified on the basis of size, shape, smell, taste, etc. Among the different germplasms, three are very distinct: i. Local monocloved-small in size having only one clove with yellowish colour of upper scale leaves, ii. Local multicloved-having 10-12 cloves with off-white colour of upper scale leaves and iii. Indian multicloved-having 10-15 cloves with brightly white upper scale leaves. Another germplasm of Allium sativum L. was found in the "Monipuri Village" (a tribal village), Moulvibazar district, Bangladesh. This plant has long been using by the tribal peoples as a substitute of garlic. The Monipuri people locally called this plant as "Joldong." This plant is almost confined to that area. It is a one-clove garlic, but the shape of the bulb and plant morphology are quite different from the local monocloved one.

The chromosomes of Allium sativum L. have been studied for decades. The diploid

* Corresponding author, e-mail: ssalam81@yahoo.com

DOI: $10.1508 /$ cytologia. 79.419 
chromosome number $2 n=16$ was well established (Katayama 1928, Levan 1931, Khoshoo and Sharma 1957, Novak 1974, Verma and Mittal 1978, Kumar and Subramaniam 1986, Mukherjee and Roy 2012). However, $2 n=11,2 n=22$ and $2 n=32$ were also reported (Novak 1974). Cui et al. (2008) found variations in karyotype within the members of this species. Vijayavalli and Mathew (1990) reported that chromosomal differences were also associated with morphological differences in some cases.

Most of the earlier chromosome studies were concentrated on conventional karyotype (Verma and Mittal 1978, Kumar and Subramaniam 1986, Mukherjee and Roy 2012) and a few with C- and NOR banding (Yuzbasioglu and Unal 2004). None of the earlier workers made any comparative karyotype study among the garlic germplasms having different numbers of cloves. Conventional karyotype analysis is unable to express critically the differences among different germplasms of a species since the germplasms of a species possess similar $2 n$ chromosome numbers and even other karyotype parameters (Khatun and Alam 2010, Khatun et al. 2011, Alam et al. 2012). Minute deletion, inversion, tandem duplication, etc. cannot be detected by conventional karyotype analysis. Therefore, a critical karyotype analysis with modern cytogenetical techniques with a combination of molecular markers is necessary for comparative study among different germplasms of Allium sativum $\mathrm{L}$.

In the present study, a combination of cytogenetical and molecular analysis was carried out for characterization of four Allium sativum L. specimens. The aims of the present study were to:

i. compare the karyotypes of the four specimens of Allium sativum L. after differential staining with orcein, CMA and DAPI,

ii. make DNA fingerprinting of each specimen by RAPD analysis, and

iii. elucidate the phylogenetic relationship among four Allium sativum L. specimens.

Materials and methods

Four specimens of Allium sativum L., viz., Local monocloved, Local multicloved, Indian multicloved and the wild specimen, were investigated in this study. Local monocloved, Local multicloved and Indian multicloved were collected from local markets of Dhaka city while the wild specimen was collected from a tribal village in Moulvibazar district, Bangladesh. These plants have been maintained in the Botanic garden, Department of Botany, University of Dhaka for more than three years.

\section{Cytogenetical study}

Healthy roots were collected and pretreated with $0.002 \mathrm{M} 8$-hydroxyquinoline for $10 \mathrm{~h}$ at 18 $20^{\circ} \mathrm{C}$ followed by $15 \mathrm{~min}$ fixation in $45 \%$ acetic acid at $4^{\circ} \mathrm{C}$. These were then hydrolyzed in a mixture of $1 \mathrm{~N} \mathrm{HCl}$ and $45 \%$ acetic acid $(2: 1)$ at $60^{\circ} \mathrm{C}$ for $3 \mathrm{~s}$. The root tips were stained in $1 \%$ aceto orcein for $1.15 \mathrm{~h}$. For CMA-banding, Alam and Kondo's (1995) method was used with slight modification. After hydrolysing and dissecting, the materials were squashed with $45 \%$ acetic acid. The slides were placed quickly in $-80^{\circ} \mathrm{C}$ freeze for $3 \mathrm{~min}$ and allowed to air dry for at least $24 \mathrm{~h}$ before study. The air-dried slides were first pre-incubated in McIlvaine's buffer ( $\mathrm{pH} 7.0$ ) for $30 \mathrm{~min}$ followed by Distamycin A $(0.1 \mathrm{mg} / \mathrm{mL})$ treatment for $10 \mathrm{~min}$. The slides were rinsed mildly in McIlvaine's buffer supplemented with $\mathrm{MgSO}_{4}(5 \mathrm{mM})$ for $15 \mathrm{~min}$. One drop of CMA $(0.1 \mathrm{mg} / \mathrm{mL})$ was added to the materials and kept for $15 \mathrm{~min}$ in a humid chamber. The slides were treated again for $10 \mathrm{~min}$ in McIlvaine's buffer with $\mathrm{MgSO}_{4}$ and $10 \mathrm{~min}$ in McIlvaine's buffer without $\mathrm{MgSO}_{4}$. Slides were mounted in $50 \%$ glycerol and kept at $4{ }^{\circ} \mathrm{C}$ overnight before observation. These were observed under a Nikon (Eclipse 50i) fluorescent microscope with blue violet (BV) filter cassette. For DAPI-staining, the method proposed by Alam and Kondo (1995) was followed after slight modifications. For counter staining, after $48 \mathrm{~h}$ of air drying, the slide was first pre-incubated in 
McIlvaine's buffer ( $\mathrm{pH} 7.0$ ) for $30 \mathrm{~min}$. The slide was treated in $0.25 \mathrm{mg} / \mathrm{mL}$ actinomycin $\mathrm{D}$ for $10 \mathrm{~min}$ in a humid chamber. After antibiotic treatment, the slide was washed with distilled water in such a way that the cover glass was removed. The slide was immersed again in McIlvaine's buffer (pH 7.0) for $15 \mathrm{~min}$ followed by treating in DAPI solution $(0.1 \mathrm{mg} / \mathrm{mL})$ for $12 \mathrm{~min}$. After rinsing in McIlvaine's buffer ( $\mathrm{pH} 7.0$ ) for $10 \mathrm{~min}$, the slide was mounted with $50 \%$ glycerol and kept at $4^{\circ} \mathrm{C}$. These were observed under a Nikon (Eclipse 50i) fluorescent microscope with ultra violet (UV) filter cassette.

\section{DNA isolation}

Leaves were harvested and total genomic DNA extracted by using a modified CTAB method (Doyle and Doyle 1987). DNA concentration was quantified through a spectrophotometer (Analylikjena, Specord 50, Germany). The A 260/280 readings for DNA samples were 1.6-1.8.

\section{PCR amplification and primer survey}

The PCR reaction mixture for $25 \mu \mathrm{L}$ contained template DNA ( $25 \mathrm{ng}) 2 \mu \mathrm{L}$, de-ionized distilled water $18.8 \mu \mathrm{L}$, Taq buffer A $10 \mathrm{X}$ (Tris with $\left.15 \mathrm{mM} \mathrm{MgCl}_{2}\right) 2.5 \mu \mathrm{L}$, primer $(10 \mu \mathrm{M}) 1.0 \mu \mathrm{L}$, dNTPs $(2.5 \mathrm{mM}) 0.5 \mu \mathrm{L}$, Taq DNA polymerase $(5 \mathrm{U} / \mu \mathrm{L}), 0.2 \mu \mathrm{L}$. PCR amplification was done in an oil-free thermal cycler (Biometra UNOII, Germany) for 46 cycles after initial denature $94^{\circ} \mathrm{C}$ for $5 \mathrm{~min}$, denature at $94^{\circ} \mathrm{C}$ for $1 \mathrm{~min}$, annealing at $36^{\circ} \mathrm{C}$ for $30 \mathrm{~s}$, extension at $72^{\circ} \mathrm{C}$ for $3 \mathrm{~min}$ and final extension at $72^{\circ} \mathrm{C}$ for $5 \mathrm{~min}$. Five primers were used from Operon Technologies, USA, viz. OPA-1 (5'-CAG GCC CTT C-3'), OPA-4 (5'-AAT CGG GCT G-3'), OPA-6 (5'-GGT CCC TGA C-3'), OPA-7 (5'-GAA ACG GGT G-3') and OPA-10 (5'-GTG ATC GCA G-3') series.

\section{Gel electrophoresis}

The amplified products were separated electrophoretically on $1 \%$ agarose gel. The gel was prepared using $1.0 \mathrm{~g}$ agarose powder containing $8 \mu \mathrm{L}$ ethidium bromide and $100 \mathrm{~mL} 1 \times \mathrm{TAE}$ buffer. Agarose gel electrophoresis was conducted in $1 \times \mathrm{TAE}$ buffer at 50 volts and $100 \mathrm{~mA}$ for $1.5 \mathrm{~h}$. DNA ladder $(1 \mathrm{~kb})$ was electrophoresed alongside the RAPD reactions as marker. DNA bands were observed on a UV-transilluminator and photographed by a gel documentation system.

\section{Scoring and data analysis}

The PCR products were analyzed after gel electrophoresis. The photographs were critically discussed on the basis of presence (1) or absence (0), size of bands and overall polymorphism of bands. These were carried out for further investigation. The scores obtained using all primers in the RAPD analysis were then pooled for constructing a single data matrix. This was used for estimating polymorphic loci, Nei (1972) gene diversity, genetic distance (D) and constructing a UPGMA (Unweighted Pair Group Method of Arithmetic Means) dendrogram among the specimen using the computer program "POPGENE" (Version 1.31).

\section{Results and discussion}

\section{Karyotype analysis}

Three Allium sativum specimens, viz., Local monocloved, Local multicloved and Indian multicloved, were found to possess $2 n=16$ chromosomes (Figs. 1-3, 5-7, 9-11). A similar chromosome number for Allium sativum was reported by earlier workers (Katayama 1928, Levan 1931, Khoshoo and Sharma 1957, Novak 1974, Verma and Mittal 1978, Kumar and Subramaniam 1986, Mukherjee and Roy 2012). On the other hand $2 n=32$ chromosomes were observed in the wild specimen (Figs. 4, 8, 12). Novak (1974) reported $2 n=32$ chromosomes of Allium sativum.

Except the wild specimen, the other three specimens had more or less similar total length of $2 n$ 


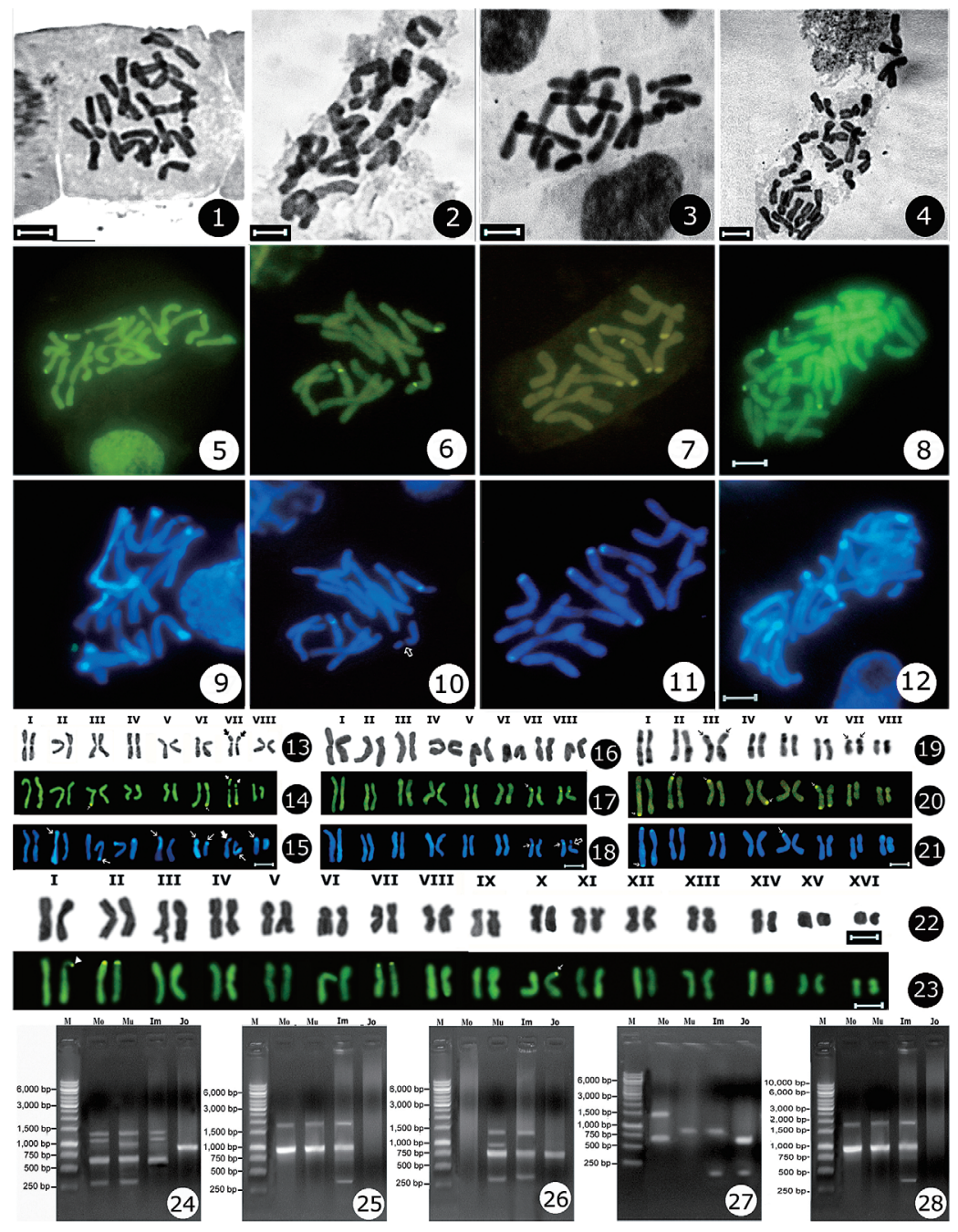

Figs. 1-28. Comparative cytogenetical and molecular analysis of four Allium sativum L. specimens: 1. Orcein-stained mitotic metaphase chromosomes of Local monocloved. 2. Orcein-stained mitotic metaphase chromosomes of Local multicloved. 3. Orcein-stained mitotic metaphase chromosomes of Indian multicloved. 4. Orcein-stained mitotic metaphase chromosomes of wild specimen. 5. CMA-stained mitotic metaphase chromosomes of Local monocloved. 6. CMA-stained mitotic metaphase chromosomes of Local multicloved. 7. CMA-stained mitotic metaphase chromosomes of Indian multicloved. 8. CMA-stained mitotic metaphase chromosomes of wild specimen. 9. DAPI-stained mitotic metaphase chromosomes of Local monocloved. 10. DAPI-stained mitotic metaphase chromosomes of Local multicloved. 11. DAPI-stained mitotic metaphase chromosomes of Indian multicloved. 12. DAPI-stained mitotic metaphase chromosomes of wild specimen. 13. Orcein-stained karyotype of Local monocloved $(2 n=16)$. 14. CMA-stained karyotype prepared of Local monocloved $(2 n=16) .15$. DAPI-stained karyotype of Local monocloved $(2 n=16)$. 16. Orcein-stained karyotype of Local multicloved $(2 n=16)$. 17. CMA-stained karyotype of Local multicloved $(2 n=16)$. 18. DAPIstained karyotype of Local multicloved $(2 n=16)$. 19. Orcein-stained karyotype of Indian multicloved $(2 n=16)$. 20. CMA-stained karyotype of Indian multicloved $(2 n=16) .21$. DAPIstained karyotype of Indian multicloved $(2 n=16)$. 22. Orcein-stained karyotype of wild specimen $(2 n=32)$. 23. CMA-stained karyotype of wild specimen $(2 n=32)$, Bar $=10 \mu \mathrm{m}$. 24 . RAPD analysis with primer OPA-1. 25. RAPD analysis with primer OPA-4. 26. RAPD analysis with primer OPA-6. 27. RAPD analysis with primer OPA-7. 28. RAPD analysis with primer OPA-10. 
Table 1. Comparative orcein, CMA and DAPI karyotype analysis of four specimens of Allium sativum L.

\begin{tabular}{|c|c|c|c|c|c|c|c|c|c|c|}
\hline Specimens & $2 n$ & $\begin{array}{l}\text { Total length } \\
\text { of } 2 n \\
\text { chromosome } \\
\text { complements } \\
\quad(\mu \mathrm{m})\end{array}$ & $\begin{array}{c}\text { Karyotype } \\
\text { formulae }\end{array}$ & $\begin{array}{l}\text { No. of } \\
\text { CMA- } \\
\text { positive } \\
\text { bands }\end{array}$ & $\begin{array}{l}\% \text { of } \\
\text { GC-rich } \\
\text { repeats }\end{array}$ & $\begin{array}{l}\text { CMA-banded } \\
\text { karyotype } \\
\text { formulae }\end{array}$ & $\begin{array}{l}\text { No. of } \\
\text { DAPI- } \\
\text { positive } \\
\text { bands }\end{array}$ & $\begin{array}{c}\text { No. of } \\
\text { DAPI- } \\
\text { negative } \\
\text { bands }\end{array}$ & $\begin{array}{l}\% \text { of } \\
\text { AT- } \\
\text { rich } \\
\text { repeats }\end{array}$ & $\begin{array}{c}\text { DAPI-banded } \\
\text { karyotype } \\
\text { formulae }\end{array}$ \\
\hline $\begin{array}{l}\text { Local } \\
\text { monocloved }\end{array}$ & 16 & 197.27 & $10 \mathrm{~m}+4 \mathrm{sm}$ & 5 & 2.28 & $3 \beta+1 \lambda+12 \delta$ & 10 & - & 35.81 & $5 \alpha+1 \beta+2 \psi+1 \pi+1 \varphi+6 \delta$ \\
\hline $\begin{array}{l}\text { Local } \\
\quad \text { multicloved }\end{array}$ & 16 & 240.73 & $8 m+8 s m$ & 3 & 1.50 & $2 \omega+1 \gamma+13 \delta$ & 2 & 1 & 1.12 & $1 \omega+1 \rho+14 \delta$ \\
\hline $\begin{array}{l}\text { Indian } \\
\text { multicloved }\end{array}$ & 16 & 203.94 & $10 \mathrm{~m}+6 \mathrm{sm}$ & 7 & 6.182 & $2 \alpha+3 \beta+1 \lambda+10 \delta$ & 6 & - & 4.85 & $4 \alpha+1 \lambda+11 \delta$ \\
\hline Wild & 32 & 315.61 & $26 \mathrm{~m}+6 \mathrm{sm}$ & 6 & 2.00 & $5 \alpha+1 \theta+26 \delta$ & 6 & - & 7.87 & $4 \alpha+1 \psi+1 \pi+26 \delta$ \\
\hline
\end{tabular}

$\mathrm{m}=$ Metacentric. $\mathrm{sm}=$ Submetacentric. $\alpha=$ Band in terminal region of short arm. $\beta=$ Band in terminal region of long arm. $\lambda=$ Band in terminal portion of both short arm and long arm. $\theta=$ Band in satellited portion. $\gamma=$ Band in centromeric region. $\omega=$ Band in just upper portion of centromeric region. $\rho=$ Band in just lower portion of centromeric region. $\psi=$ Band in entire length of whole chromosome. $\pi=$ Band in whole short arm and adjacent part of long arm near centromere. $\delta=$ No band.

chromosome complement. In contrast, the total length of $2 n$ chromosome complement of the wild specimen was about one and a half times bigger than the other three specimens (Table 1).

The range of chromosomal length of the wild specimen was $4.50-14.92 \mu \mathrm{m}$. The length of the smallest chromosome of this specimen is about half than the other three specimens.

The four specimens showed distinct centromeric formulae, i.e. $12 \mathrm{~m}+4 \mathrm{sm}$ for Local monocloved, $8 \mathrm{~m}+8 \mathrm{sm}$ for Local multicloved, $10 \mathrm{~m}+6 \mathrm{sm}$ for Indian multicloved and $26 \mathrm{~m}+6 \mathrm{sm}$ for the wild specimen (Table 1). This result indicated that Local multicloved possesses a comparatively heterogeneous karyotype. In contrast, the wild specimen has a comparatively homogenous karyotype. According to Stebbins (1971) the former specimen is relatively advanced while the later is primitive in respect of karyotype asymmetry.

\section{Asymmetric pair}

In the Indian multicloved specimen, asymmetry regarding the centromeric position was found in pair III and VII (Fig. 19, arrow). In these two pairs, one chromosome was metacentric and the other sub-metacentric. In pair VII, the lengths of long arm of both the chromosomes were exactly the same while the length of short arm in sub-metacentric chromosome was smaller than that of its homologue pair. In pair III, the length of long arm of a member was bigger and short arm was smaller than that of its respective homologue member. Deletion of chromosomal segment was reported in Allium sativum (Verma and Mittal 1978). Khandaker et al. (2007) found deletions in a variety of Lens culinaris. Sumner (1990) mentioned that if the deleted portion was composed of heterochromatin, usually there was no effect on phenotype. The probable reason for the asymmetry pair found in Indian multicloved specimens was due to a deletion of heterochromatic chromosomal segment from the respective chromosomes.

\section{A possible homozygous paracentric inversion}

In the Local monocloved specimen, both the members of chromosome pair VII are submetacentric. In between long arm and short arm, a darkly stained prominent and spherical structure was found (Figs. 13, 14, 15, thick arrow). There was a distinct gap present between the spherical structure and the short arms of both the chromosomes. Verma and Mittal (1978) reported similar chromosomes in a member of pair VI and VII of this specimen. They mentioned the upper terminal part of these chromosomes as satellite. From this experiment it can be assumed that initially the satellite portions were small knob-like structure and present at the terminal end of the short arm. A 
homozygous paracentric inversion might take place in this pair by which the terminal knob-like structure rotated by a $180^{\circ}$ angle and placed near the centromere and thus looked like darkly stained spherical structures at those portions.

\section{CMA- and DAPI-karyotypes}

The four specimen of Allium sativum have distinct CMA banding patterns. The presence of CMA bands revealed the GC-rich portions (Schweizer 1976). The percentage of GC-rich portions of the four specimens was very small, ranging from 1.50-6.18 (Table 1). The CMA bands in the four specimens present at the terminal region of the specific chromosomes indicated the equilocal distribution of GC-rich portions. Sumner (1990) mentioned that heterchromatins have a tendency to distribute at the equilocal regions of different non-homologous chromosomes. Therefore, the CMA bands of the four specimens may be heterochromatic in nature.

The DAPI banding karyotypes of the four specimens were completely different. DAPI bands are AT-rich in nature (Schweizer 1976). The AT-rich percentage varied sharply in the four specimens, ranging from 1.12-35.81 (Table 1). In the Local monocloved, the bands were thicker and brighter. One member of pair II and VI fluoresced entirely with DAPI. One member of V and VII fluoresced for half of the length in this specimen. The other bands were very thick and occupied comparatively large areas. This type of banding pattern was not found in the other three specimens. The DAPI positive bands in the other three specimens were minute and localized to a particular region of the chromosomes. In respect of DAPI karyotypes, the Local monocloved specimen could be differentiated from the other three specimens (Figs. 15, 18, 21, Table 1).

\section{Marker chromosomes}

The entirely DAPI fluoresced chromosomes in the Local monocloved specimen could be isolated from the rest of the chromosomes (Fig. 15). In the Indian multicloved specimen, a member of pair I had DAPI-positive bands at two terminal ends (Fig. 21). This chromosome showed a CMA-positive band at the lower terminal end. In the same specimen, a DAPI and a CMA band were found at the same location in a member of pair III and VI (Figs. 20, 21, arrow). The CMA and DAPI bands at the same regions of chromosomes indicated the tandem presence of GC- and ATrich repeats. These two chromosomes of this specimen could be used as marker for this specimen. One chromosome in the Local monocloved and Indian multicloved had CMA band in both the terminal regions. These chromosomes are unique and thus can be used as marker chromosomes of these two specimens. Moreover, in Local multicloved, a bright CMA positive band was found at the centromeric region in a member of pair VIII. A deep negative band (non-staining) was found at the same region after counter staining with DAPI (Figs. 17, 18, thick arrow). CMA-positive and DAPI-negative indicated that these portions are completely rich in GC-base pairs (Sumner 1990, Alam et al. 2011). This chromosome could be used as a marker for the local multicloved specimen.

\section{RAPD fingerprinting}

Each specimen showed characteristic RAPD fingerprinting. The Local multicloved specimen showed one band of $900 \mathrm{bp}$ with primer OPA-1 while the wild specimen had one band of $1000 \mathrm{bp}$ with the same primer (Fig. 24). With OPA-4, a unique fragment of $400 \mathrm{bp}$ was found in the Indian multicloved (Fig. 25, Table 2). The Local multicloved specimen had a unique fragment of $900 \mathrm{bp}$ with primer OPA-6 (Fig. 26, Table 2). The Local monocloved showed one unique fragment of $1500 \mathrm{bp}$ with primer OPA-7. The Indian multicloved specimen showed a unique band of $200 \mathrm{bp}$ with primer OPA-10 (Fig. 28). These bands were unique since they were absent in other specimens with these primers. The unique RAPD fragments could be used as markers for the respective specimens. 
Table 2. Compilation of RAPD analysis of four Allium sativum L. specimens.

\begin{tabular}{lcccccc}
\hline \hline $\begin{array}{c}\text { Primer } \\
\text { codes }\end{array}$ & $\begin{array}{c}\text { Sequences } \\
\left(5^{\prime}-3^{\prime}\right)\end{array}$ & $\begin{array}{c}\text { Total } \\
\text { bands }\end{array}$ & $\begin{array}{c}\text { Size ranges } \\
(\mathrm{bp})\end{array}$ & $\begin{array}{c}\text { No. of } \\
\text { polymorphic } \\
\text { bands }\end{array}$ & $\begin{array}{c}\text { No. and size (bp) of germplasms } \\
\text { specific unique bands }\end{array}$ & $\begin{array}{c}\text { Polymorphisms } \\
(\%)\end{array}$ \\
\hline OPA-1 & CAG GCC CTT C & 14 & $300-1400$ & 14 & $\begin{array}{c}900 \mathrm{bp} \text { in Local multicloved and } \\
1000 \text { bp in Wild-Joldong }\end{array}$ & 100.00 \\
OPA-4 & AAT CGG GCT G & 7 & $400-1900$ & 5 & 1000 bp in Indian multicloved & 71.43 \\
OPA-6 & CAG GCC CTT C & 8 & $300-1400$ & 7 & 900 bp in Local multicloved & 87.50 \\
OPA-7 & GAA ACG GGT G & 5 & $200-1500$ & 5 & 1500 bp in Local Monocloved & 100.00 \\
OPA-10 & GTG ATC GCA G & 6 & $200-1400$ & 6 & 200 bp in Indian multicloved & 100.00 \\
\hline
\end{tabular}

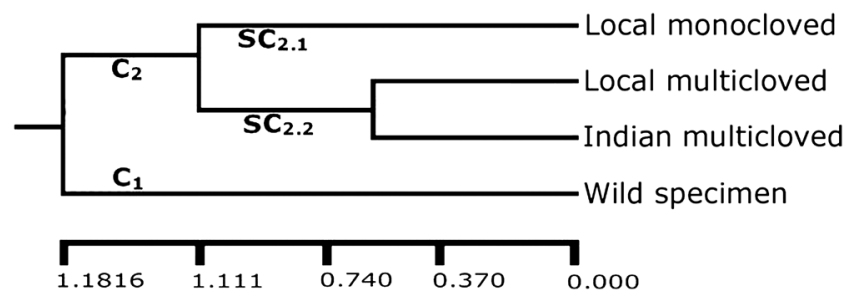

Fig. 29. UPGMA dendrogram constructed based on Nei's (1972) genetic distance summarizing the data on differentiation between four Allium sativum L. specimens by RAPD analysis.

\section{Cluster analysis}

On the basis of RAPD banding pattern, the four specimens were grouped into two major clusters (Fig. 29). The wild specimen was completely different from the other three and placed alone in a cluster. The other three specimens were grouped in another cluster in which the Local multicloved and the Indian multicloved made a sub-cluster with the narrowest genetic distance (Fig. 29).

\section{Multicloved not polyploid of monocloved}

Although the gigas features of multicloved specimen are supposed to consider it an autopolyploid of monocloved, no such karyotype indication was obtained in the present research. Both multicloved and monocloved specimens possessed $2 n=16$ chromosomes with almost similar total length of $2 n$ chromosome complements (Table 1). Therefore, multicloved specimens used in this study were not actually the polyploid of monocloved specimen.

\section{Status of the wild specimen}

This specimen showed completely different karyotype features than the other three specimens as listed below.

i. It has $2 n=32$ chromosomes instead of the usual $2 n=16$ (Figs. 4, 8, 12, 22, 23). $2 n=32$ chromosomes for Allium sativum is very rare. Only an earlier worker (Novak 1974) reported $2 n=32$ for this species.

ii. The total length of chromosome complement was one and a half times bigger than the other three specimens (Table 1).

iii. The smallest chromosomes of this specimen was $4.5 \mu \mathrm{m}$, which is half than that of the Local monocloved and the Indian multicloved and one-third than the smallest chromosomes of the Local multicloved (Table 1).

iv. The centromeric formula was different comprising of mostly metacentric chromosomes (Table 1).

v. The CMA- and DAPI-banding patterns are different (Figs. 14, 15, 17, 18, 20, 21, 23). 
vi. On the basis of RAPD fingerprinting, this specimen was placed alone in a different cluster with the highest genetic distance (Fig. 29).

vii. The 32 chromosomes could easily be arranged in 16 pairs. The centromeric position and the length of the adjacent pairs were so distinct that four chromosomes could not be arranged in a group (Fig. 22). CMA and DAPI banding did not show similar banding in four chromosomes (Figs. 8, 12, 23).

The present data did not support to consider this specimen as an auto-tetraploid. Therefore, a thorough revision is necessary to elucidate the taxonomic status of this specimen.

\section{References}

Alam, Sk. S., Jahan, N., Habib, M. A. and Islam, M. N. 2012. Cytogenetical and molecular characterization of five commercial variety in Trichosanthes anguina L. Cytologia 77: 155-162.

Alam, Sk. S. and Kondo, K. 1995. Comparative C-banding and fluorescent banding analysis of seven species of Australian Drosera (Droseraceae). Cytologia 61: 383-394.

Cui, X., Ao, C., Zhang, Q., Chen, L. and Liu, J. 2008. Diploid and tetraploid distribution of Allium przewalskianum Regel, (Liliaceae) in the Qinghai-Tibetan Plateau and adjacent regions. Caryologia 61: 192-200.

Doyle, J. J. and Doyle, J. L. 1987. A rapid DNA isolation procedure from small quantities of fresh leaf tissues. Phytochem. Bull. 19: 11-15.

Katayama, Y. 1928. The chromosome number in Phaseolus and Allium, and an observation on the size of stomata in different species of Triticum. J. Sci. Agric. Soc. Tokyo 303: 52-54.

Khandaker, M., Hoque, M. I. and Alam, Sk. S. 2007. Fluorescent banding in three varieties of Lens culinaris Medik (Fabaceae). Cytologia 72: 227-231.

Khatun, M. and Alam, Sk. S. 2010. Conformation of species status of Corchorus trilocularis by differential chromosome banding and isozyme assay. Cytologia 75: 83-88.

Khatun, M., Sultana, S. S., Ara, H., Islam, M. N. and Alam, Sk. S. 2011. Differential chromosome banding and isozyme assay of three Corchorus spp. Cytologia 76: 27-32.

Khoshoo, T. N. and Sharma, V. B. 1957. Chromosome number of north Indian garlic. Curr. Sci. $26: 62$.

Kumar, V. and Subramaniam, B. 1986. Chromosome Atlas of Flowering Plants of the Indian Subcontinent, Monocotyledons. Volume 2. Botanical Survey of India, Calcutta. pp. 465-1095.

Levan, A. 1931. Cytological studies in Allium. A preliminary note. Heriditas 15: 347-356.

Mukherjee, A. and Roy, S. C. 2012. Karyotype analysis of five species of Allium. Indian J. Fund. App. Life Sci. 2: 374383.

Nei, M. 1972. Genetic distance between populations. Am. Nat. 106: 283-292.

Novak, F. J. 1974. The changes of karyotype in callus cultures of Allium sativum L. Caryologia 27: 45-54.

Schweizer, D. 1976. Reverse fluorescent chromosome banding with chromomycin and DAPI. Chromosoma 58: 307-324.

Siddiqui, K. U., Islam, M. A., Ahmed, Z. U., Begum, Z. N. T., Hassan, M. A., Khondker, M., Rahman, M. M., Kabir, S. M. H., Ahmad, M., Ahmed, A. T. M., Rahman, A. K. A. and Haque, E. U. (eds.) 2007. Encyclopedia of Flora and Fauna of Bangladesh. Angiosperms: Monocotyledons (Agavaceae-Najadaceae). Volume 11. Asiatic Society of Bangladesh, Dhaka. pp. 335-336.

Stebbins, G. L. 1971. Chromosomal Evolution in Higher Plants. Addison-Wesley Publishing Company, Menlo Park.

Sumner, A. T. 1990. Chromosome Banding. Unwin Hyman, London.

Verma, S. C. and Mittal, R. K. 1978. Chomosomal variation in the common garlic, Allium sativum L. Cytologia 43: 383396.

Vijayavalli, B. and Mathew, P. M. 1990. Cytotaxonomy of the Liliaceae and Allied Families. Continental Publications, Trivandrum.

Yuzbasioglu, D. and Unal, F. 2004. Karyotyping, C- and NOR-banding of Allium sativum L. (Liliaceae) cultivated in Turkey. Pak. J. Bot. 36: 343-349. 